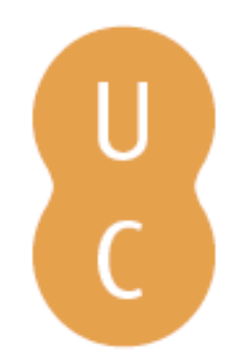

\title{
nommalina
}

\section{As origens da urbe e o período da monarquia}

Autor(es): $\quad$ Leão, Delfim; Brandão, José Luís

Publicado por: Imprensa da Universidade de Coimbra

URL

persistente: URI:http://hdl.handle.net/10316.2/36910

DOI: $\quad$ DOI:http://dx.doi.org/10.14195/978-989-26-0954-6_2

Accessed : $\quad$ 26-Apr-2023 07:31:02

A navegação consulta e descarregamento dos títulos inseridos nas Bibliotecas Digitais UC Digitalis, UC Pombalina e UC Impactum, pressupõem a aceitação plena e sem reservas dos Termos e Condições de Uso destas Bibliotecas Digitais, disponíveis em https://digitalis.uc.pt/pt-pt/termos.

Conforme exposto nos referidos Termos e Condições de Uso, o descarregamento de títulos de acesso restrito requer uma licença válida de autorização devendo o utilizador aceder ao(s) documento(s) a partir de um endereço de IP da instituição detentora da supramencionada licença.

Ao utilizador é apenas permitido o descarregamento para uso pessoal, pelo que o emprego do(s) título(s) descarregado(s) para outro fim, designadamente comercial, carece de autorização do respetivo autor ou editor da obra.

Na medida em que todas as obras da UC Digitalis se encontram protegidas pelo Código do Direito de Autor e Direitos Conexos e demais legislação aplicável, toda a cópia, parcial ou total, deste documento, nos casos em que é legalmente admitida, deverá conter ou fazer-se acompanhar por este aviso.

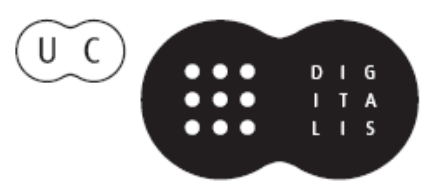


JOSÉ LUÍS BRANDÃO FRANCISCO DE OLIVEIRA (COORD.)

IMPRENSA DA

UNIVERSIDADE

DE COIMBRA

COIMBRA

UNIVERSITY

PRESS
HISTÓRIA DE
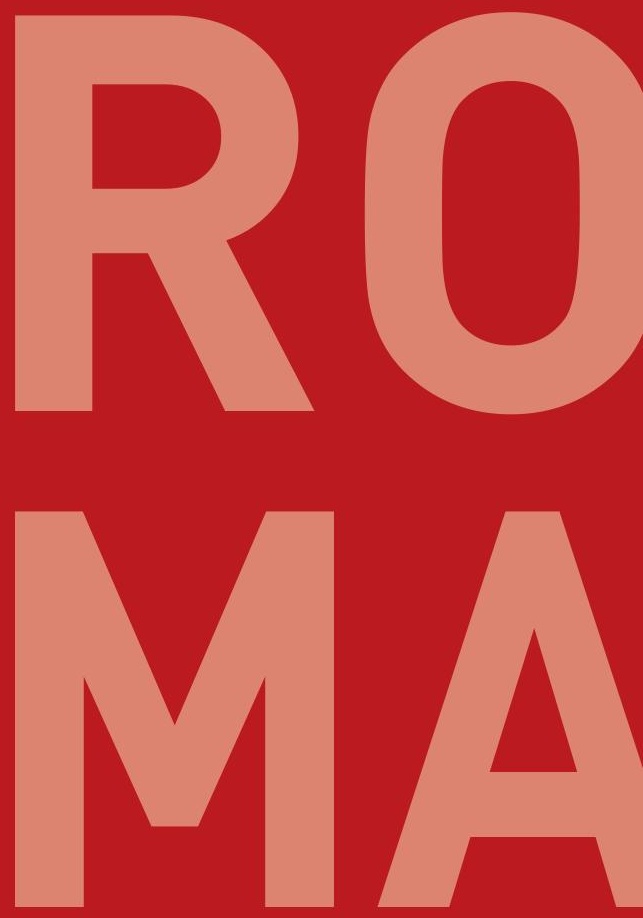

ANTIGA

VOLUME I

DAS ORIGENS À

MORTE DE CÉSAR 


\section{AS ORIGENS DA URBE E O PERÍODO DA MONARQUIA}

Delfim Leão \& José Luís Brandão Universidade de Coimbra Centro de Estudos Clássicos e Humanísticos

Sumário: A tradição lendária sobre as origens de Roma. A crítica da tradição literária e o confronto com os dados da arqueologia. A Monarquia romana: os sete reis da tradição e os principais feitos a eles atribuídos. Caraterísticas da Monarquia romana e sua evolução. Instituições sociais e políticas que tiveram origem na época monárquica.

\section{As origens de Roma}

\subsection{Breve síntese da tradição literária}

A tradição literária antiga (plasmada sobretudo em Tito Lívio, Dionísio de Halicarnasso e Plutarco) liga a história de Roma à destruição de Tróia. Eneias com o filho Ascânio (ou Iulo) desembarca no Lácio, junto à foz do Tibre. Aqui, desposa a filha de Latino, rei local, e funda a cidade de Lavínio. Ascânio funda mais tarde a cidade de Alba Longa, nos Montes Albanos, e depois lhe sucederão doze reis. Dá-se uma crise dinástica, quando Amúlio 
usurpa o trono a seu irmão Numitor e transforma a filha deste (Reia Sílvia) em vestal. É esta a base da história depois trabalhada de formas várias pelos autores, dando origem a uma infinidade de pequenas variantes ${ }^{1}$.

A principal tradição apresentava Rómulo e Remo como filhos de Reia Sílvia, que era por sua vez filha do rei Numitor, o legítimo herdeiro do trono albano, deposto pelo irmão Amúlio. Amúlio obrigou a sobrinha a fazer-se Vestal, de forma a evitar a eventual reivindicação do trono por algum descendente de Numitor. Como as servidoras de Vesta tinham de permanecer virgens, o nascimento dos gémeos encontrava-se, de certa forma, envolto em polémica e infração, o que teria facilitado a decisão de Amúlio de mandar lançar as crianças ao Tibre. Da piedade ou receio da pessoa encarregada de cumprir a sentença resultou que os dois irmãos foram colocados numa cesta que, ao ser arrastada rio abaixo pela corrente, acabaria depositada no banco de areia de uma das margens. Uma vez aí, os gémeos foram amamentados por uma loba, até que uns pastores os recolheram e criaram. Rómulo e Remo cresceram nesse meio, desconhecendo a sua verdadeira identidade, embora as suas naturais qualidades de liderança os projetassem como chefes dos companheiros, que se envolviam em frequentes escaramuças e bravatas com outros pegureiros, piratas e ladrões que atuassem na região. Ao tomarem conhecimento da sua real ascendência, os gémeos atacaram Alba Longa e repuseram no trono o avô, Numitor, embora optassem por não permanecer na cidade, cujo governo lhes caberia mais tarde por direito. Em vez disso, decidiram fundar uma colónia de Alba Longa, no local onde haviam sido salvos. A nova urbe acabaria por chamar-se Roma, designação que derivaria de Rómulo, depois de ele ter assassinado o irmão numa querela fútil, por alturas da delimitação das muralhas da cidade. Roma conheceu um crescimento rápido, devido sobretudo à grande capacidade de integração e

\footnotetext{
${ }^{1}$ Sobrevive mesmo um texto de um livro dedicado integralmente a esse problema (Origo gentis Romanae), tradicionalmente atribuído ao historiador Aurélio Victor, que se terá baseado num trabalho antiquário do tempo de Augusto, o qual recolhia já contributos dos séculos anteriores. Cf. Cornell 1995 57-58; Rodrigues 2005 59-138. Vide ainda Leão 2008 97-99, de onde é retirada boa parte desta síntese geral, conjugada em particular com as abordagens de Grimal 1993 e de Cornell 1995.
} 
acolhimento de outras pessoas, mesmo de elementos marginais e potencialmente perigosos (pobres, devedores, fugitivos, escravos), que, sendo na maioria homens, terão sido forçados a raptar as Sabinas para garantir descendência, o que desencadeou uma guerra com os Sabinos e a posterior fusão das duas comunidades, com Rómulo e Tito Tácio à cabeça. Após a morte de Tito Tácio (com suspeitas ligadas a Rómulo), este último governou por muitos anos, com sucesso tanto na paz como na guerra. Roma continuou a aumentar em poder e importância demográfica, numa expansão rápida, justificada essencialmente por dois fatores: por um lado, a poderosa força bélica, que ora atraía e forçava a celebração de alianças com os vizinhos ora permitia infligir pesadas derrotas aos inimigos; por outro, a enorme capacidade para absorver elementos externos, fossem imigrantes, confederados ou mesmo as partes vencidas em conflito.

\subsection{Variantes e peculiaridades da tradição}

Os antigos viam em Rómulo o fundador de Roma, numa data que situavam em meados do séc. VIII a.C., se bem que também eles se apercebessem de algumas das dificuldades cronológicas criadas por esta forma de organizar o passado, em especial no que se referia à articulação com os relatos da viagem de Eneias até ao Lácio. Uma vez que, tradicionalmente, a guerra de Tróia era colocada à volta do séc. XII a.C., Eneias teria fundado Lavínio pouco depois desse evento e, por conseguinte, os gémeos não poderiam estar ligados a esse herói por um laço de parentesco próximo, na medida em que, entre as duas gerações, mediavam cerca de quatrocentos anos. Ora esse espaço vai ser preenchido pela dinastia dos reis albanos, iniciada por Ascânio, filho de Eneias, ao fundar Alba Longa ${ }^{2}$.

Apesar da concordância genérica sobre as origens de Roma, as fontes comportam inúmeras disputas e variantes no respeitante a questões de pormenor. A controvérsia começava logo pela paternidade dos gémeos.

\footnotetext{
2 Vide Leão 2008 11. Outras versões chegavam mesmo a ligar a origem de Roma a personagens como Hércules e Evandro; para mais pormenores, vide Cornell 1995 68-69.
} 
A maioria das fontes identificava o pai das crianças com o deus Marte, solução que reunia evidentes vantagens: enobrecia as origens de Roma, ao misturar elementos humanos e divinos, além de que ter Marte como pai era um cenário muito conveniente a um povo que se afirmara pela capacidade bélica ou 'marcial'. Por outro lado, esta solução ilibava Reia Sílvia da acusação de não ter observado voluntariamente a castidade. Ainda assim, havia outros candidatos à paternidade, como um espectro saído da terra (hipótese que salvaguardava a ideia de intervenção divina) ou simplesmente o próprio Amúlio, que se disfarçara de Marte para violentar a sobrinha. Objeto de especulação era ainda a identificação da loba que amamentara os gémeos. De facto, os antigos já sublinhavam a ambiguidade do termo latino lupa, pois tanto pode significar 'loba' como 'prostituta' 3 , de modo que a racionalização do mito implicava, em última análise, estabelecer a diferença entre uma leitura enobrecedora ou, muito pelo contrário, aviltante ${ }^{4}$. Mas os Romanos gostavam de chamar-se 'filhos da loba' e conviviam bem com a ambiguidade dessa designação.

Idêntica discussão motivava o contexto em que ocorrera a morte de Remo, oscilando os juízos entre a recriminação aberta de Rómulo (que vinha enganando o irmão já desde a consulta do voo das aves, a propósito da decisão sobre o nome e localização da futura cidade) ou as tentativas de desculpabilização, assumindo que tinha sido um companheiro de armas (Célere) e não Rómulo a desferir o golpe mortal.

Rómulo enfrentava a mesma ambivalência interpretativa relativamente às circunstâncias que levaram ao assassinato do sabino Tito Tácio ou à sua própria morte. No primeiro caso, era, no mínimo, acusado de alguma incúria na maneira como procurara fazer justiça ao assassínio do colega de governo, chegando inclusive a enfrentar a suspeita de ele mesmo ter organizado o golpe, a fim de ficar sozinho à frente de Roma. Quanto ao desaparecimento do corpo de Rómulo, no termo de uma progressiva cedência aos vícios da tirania, havia duas versões: a racional, que dizia que ele fora assassinado e esquartejado numa conjura do senado, tendo

\footnotetext{
3 Repare-se no significado do termo português 'lupanar': 'casa de prostituição', 'bordel'.

${ }^{4}$ Ambiguidade espelhada em Plu. Rom. 4.4-5.
} 
cada senador levado uma parte do seu corpo; e a pia, que propunha um arrebatamento por intervenção divina. Por outras palavras, oscilava-se entre o homicídio politicamente motivado e a apoteose do herói fundador.

\subsection{Breve análise crítica das lendas fundacionais}

A ligação à guerra de Tróia. A análise destes relatos patenteia a fusão de elementos itálicos com outros de origem grega. Com efeito, a lenda de Eneias tem uma origem grega, com raízes épicas: na Ilíada, Eneias é uma figura proeminente, embora menor: foi o único dos troianos ilustres a escapar à guerra. Um passo famoso na Ilíada (20.307-308) vaticina que ele iria um dia governar os Troianos ${ }^{5}$, mas como não havia nenhuma dinastia de Eneias a governar a Tróade na época histórica, os Gregos começaram a especular que Eneias pudesse ter estabelecido o seu reinado noutro sítio, tradição desde cedo bem firmada em espaço helénico ${ }^{6}$. A lenda de Eneias parece portanto fruto da complexa história das relações políticas e culturais entre Roma e os Gregos ${ }^{7}$.

A tradição sustenta que as cidades do Lácio eram todas colónias de Alba Longa e que Roma seria a última delas, mas a arqueologia não confirma esses factos. Com efeito, o pressuposto de que Lavínio e Alba eram cidades muito mais antigas do que Roma tem origem provável na necessidade de preencher o intervalo entre Eneias (e a Guerra de Tróia, em c. 1200 a.C.) e Rómulo (no séc. VIII a.C.). Mas, como salienta Cornell

5 Ponto reforçado no Hino Homérico a Afrodite, 5.195-199.

${ }^{6}$ Nomes sugestivos de lugares, imaginação poética e amplificação antiquária terão feito o resto. Já no séc. VI a.C., havia moedas cunhadas na Macedónia com Eneias a carregar Anquises das ruínas de Tróia. A datação desta conexão entre Roma e a Hélade é controversa, mas a maioria dos estudiosos pensa que a lenda já estava bem estabelecida na Itália central desde muito cedo, talvez no séc. VI a.C. ou mesmo antes, até porque a influência grega era muito grande nessa altura, conforme mostra a arqueologia. Cf. Cornell $199563-$ -68; Forsythe 2005 93-94.

7 Conforme salienta Cornell 1995 65, as vantagens políticas desta lenda manifestaram-se pela primeira vez em 263 a.C., durante a guerra contra Cartago, altura em que a cidade siciliana de Segesta se aliou a Roma por causa da sua ascendência troiana comum, sendo particularmente úteis quando Roma começou a interferir nos assuntos da Ásia Menor. 
(1995 71-72), é mais provável que a ideia da proeminência de Alba e de Lavínio resulte da sua importância como centros religiosos (no Mons Albanus havia um festival em honra de Júpiter Laciar e, em Lavínio, celebrava-se o culto de Eneias e dos Penates), proeminência essa que a tradição transformou em hegemonia política sobre o Lácio.

No que respeita à sua validade, as tradições sobre a fundação de Roma desde Eneias a Rómulo não podem ser consideradas uma narrativa histórica. Como herói épico, Eneias está em posição um tanto mais confortável, mas o seu peso histórico não será maior do que o dos outros heróis homéricos e a sua relação direta com a migração para ocidente não pode ser estabelecida em termos minimamente seguros. Mas, como diz o próprio Tito Lívio no início da sua obra Desde a fundação da cidade (Praef. 6-7), "se os factos anteriores ao fundação da Urbe, ou atinentes à fundação, são no processo de transmissão ilustrados mais por fábulas poéticas do que por documentos históricos incorruptos, não está nos meus desígnios nem confirmá-los, nem refutá-los. Esta é a concessão que se faz à antiguidade, para através da mistura do humano com o divino tornar mais venerandas as origens das cidades».

Os filhos da loba. A lenda de Rómulo é de clara origem latina, sem que se possa estabelecer a data exata da sua formação ${ }^{8}$. Há razões para crer que era já corrente na época arcaica, como o prova uma estatueta em bronze da loba, que é provavelmente do séc. VI a.C.9. Em 269 a.C. aparece mesmo em cunhagens, pelo que não poderia derivar de uma eventual propaganda hostil a Roma, de introdução recente. Várias são as explicações para o seu aparecimento: religiosas, étnicas, políticas, sociais e linguísticas ${ }^{10}$. O nome Romulus sugere um epónimo formado a partir

\footnotetext{
8 No chamado espelho de Bolsena (séc. IV a.C.), onde surge a mais antiga figuração dos gémeos, o grande ausente é Eneias, pelo que se deduz que o artefacto reproduz o estrato mítico indígena. Vide Carandini 2009 32-33.

${ }^{9}$ Essa estátua encontra-se, agora, no Palazzo dei Conservatori. De resto, o mais tardar c. de 300 a.C., a história dos gémeos já se havia tornado na versão-padrão em Roma.

10 Pode significar o culto totémico do lobo (próprio de civilizações pastoris); temas mitológicos greco-etruscos (cerva de Télefo e a loba de Bolónia); dualidade étnica (Romanos e Sabinos) ou política (patrícios e plebeus), através de duas etimologias (grega Rhomos e latina Romulus) para o epónimo do fundador da cidade. Tudo enquadrado numa cenografia local: gruta do Palatino (Lupercal) e figueira (Ruminal). O nome da figueira derivava do
} 
do nome da cidade, que significa apenas 'romano' (como Siculus significa 'siciliano'), pelo que pode não ter existido nenhum herói com esse nome. É também claro que a história possui elementos populares, que são ecoados em mitos e lendas de muitas outras sociedades do mundo antigo, sublinhando o nascimento e crescimento de pessoas que hão de marcar o futuro de cidades e civilizações (como reis, fundadores ou heróis ${ }^{11}$ ).

Também são falantes os nomes do pastor que recolheu os gémeos Fáustulo (que traz consigo um vaticínio favorável, uma vez que deriva de fauere 'ser favorável') -, e o de Larência, que os criou (como assinala Grimal 1993 18). Por detrás deles adivinham-se associações a divindades: Fáustulo evoca o deus pastoril Fauno, e Larência faz lembrar os Lares, alvos da devoção privada e pública. Mas, acrescente-se, parece significativo que tenha sido também associada ao culto dos mortos, os Larentalia (a 23 dezembro), celebração funerária a que se juntavam lendas de fecundidade. Apesar de lendário, o enquadramento desta informação acaba sendo, portanto, confluente com os dados da arqueologia. A cabana de Fáustulo, segundo a tradição, erguia-se no Palatino com o seu telhado de colmo e paredes de adobe, e, no final da República, os Romanos ainda a podiam contemplar ${ }^{12}$.

Fundação e desenvolvimento da cidade. Cícero (Rep. 2.3.5) fala sobre a localização da nova cidade lançada por Rómulo (sem pôr em causa a sua existência histórica), salientando a habilidade tática do fundador, ao evitar expor a nova cidade aos perigos que mais facilmente poderiam chegar por mar. Em boa verdade, como oportunamente salienta Grimal (1993 12-14), Cícero descurou o facto de que a Roma primitiva era insalubre e pantanosa (como mostram as cabanas assentes em estacas de

facto de ficar junto do santuário de Rumina, uma divindade protetora das aleitantes. De resto, como o alfabeto etrusco não tinha a vogal $o$, o nome de Roma era escrito naquela língua como Ruma, o que em latim significava 'teta'.

${ }^{11}$ Exemplos bem conhecidos são Ciro da Pérsia, Íon ancestral dos Iónios, os príncipes troianos Páris e Eneias, os heróis gregos Perseu e Édipo, o caso de Egisto (assassino de Agamémnon) ou de Cípselo tirano de Corinto. De resto, o próprio conto da natividade cristã partilha, em termos latos, muitos destes motivos do conto popular. Mais pormenores em Cornell 1995 61-63; Forsythe 200595.

12 Vide Rodrigues 2005 151-154; Forsythe 200584. 
madeira), carecendo inclusive de água potável, facto que obrigaria a cavar poços e a fazer cisternas. As razões para a escolha do local devem ter sido estratégicas: tratava-se da ponta ocidental de um vasto planalto, que entroncava, para leste, nos Montes Albanos. Os colonos elegeram, assim, um lugar forte nas colinas, favorecido pela proteção conjunta de pântanos e do rio Tibre. Era também um lugar propício do ponto de vista comercial: situava-se, com efeito, no cruzamento de vias entre a Etrúria e o Lácio (e na travessia para a Campânia) e entre as salinas da foz do Tibre e a rota para os Apeninos, a que mais tarde se chamará Via Salaria.

Os achados arqueológicos atuais fornecem um quadro do desenvolvimento das primitivas comunidades latinas, desde pequenas aldeias a povoados maiores, durante a Idade do Ferro. A arqueologia e a tradição literária combinam-se para sugerir que o Palatino foi o núcleo inicial do povoado, já que os restos de aldeias foram postos ali a descoberto, bem como a necrópole do Foro, remontando a meados do séc. VIII a.C. Nesta perspetiva, parece confirmar-se a formação da cidade como expansão de um núcleo primitivo, se bem que o conhecimento da arqueologia de Roma não permita tirar conclusões seguras. Encontraram-se no Palatino resquícios de cabanas da cultura lacial (meados do séc. VIII, embora se saiba que esta não foi a primeira ocupação do local, habitado desde 1000 a.C.). Mas também há dados que apontam para a fusão de vários núcleos iniciais: certos costumes e cerimónias religiosas arcaicos ${ }^{13}$ datam desse período, guardando a memória de um momento em que o lugar de Roma era ocupado por pequenas aldeias que se reagruparam.

A lenda do rapto das Sabinas constitui um indício de que a população originária de Roma era uma mistura de elementos das duas etnias. Com efeito, segundo a lenda, o embate entre as duas comunidades termina com

13 Um festival referido pelos antiquários antigos como Septimontium, que envolvia sete áreas da cidade, pode estar na origem da ideia de Roma como cidade das sete colinas. Este festival ocorria a 11 de dezembro, no encerramento do ano agrícola. Esta organização parece corresponder à fase proto-urbana de Roma: segundo Carandini 2009 22-26, remontará ao período entre 850 e 750 a.C. Além disso, o colégio sacerdotal dos Sálios estava dividido em dois subgrupos, os Salii Palatini e os Salii Collini, que representavam respetivamente os montes Palatino e Quirinal. Levavam a cabo cerimónias no final do ano civil e começo do novo (em março). Vide Forsythe 2006 80-82; 85. 
a fusão de Romanos e Sabinos, sob o governo de Rómulo e Tito Tácio. Essa ideia está, de resto, presente em toda a tradição romana sobre a Monarquia: dos primeiros quatro reis, dois eram latinos (Rómulo e Tulo Hostílio) e dois sabinos (Numa Pompílio e Anco Márcio) - ou três, se contarmos também Tito Tácio. A arqueologia, a linguística e a dialetologia não dão propriamente base de sustentação histórica para a lenda das Sabinas, mas também não negam cabalmente a presença do elemento sabino na Roma monárquica ${ }^{14}$, tanto mais que a presença de Sabinos na República foi um facto, e várias famílias reclamavam essa origem, a começar pela dos Cláudios ${ }^{15}$. Portanto, nada parece impedir que este fluxo da tradição possa ecoar um dado histórico e culturalmente antigo.

\subsection{Conclusões sobre as lendas da fundação}

No geral, as narrativas da fundação de Roma (de Eneias a Rómulo) não podem ser consideradas históricas: representam uma complexa mistura de lendas, contos populares e reflexão erudita, sendo, no entanto, importantes para o estudo da historiografia romana e para o desenvolvimento da consciência identitária dos Romanos. Coloca-se, por conseguinte, a questão de saber se as lendas fundacionais foram recolhendo, ao longo do seu processo de formação, o essencial da Romanitas ou se constituirão antes, pelo contrário, uma projeção no passado da forma como os Romanos se viam a si mesmos e gostavam de ser vistos pelos outros. A resposta residirá, possivelmente, a meio caminho entre ambas as hipóteses formuladas. Em todo o caso, isso não altera - mas antes reforça - a dimensão paradigmática e simbólica da tradição. Estas lendas mostram, primeiro, que a identidade do povo romano provém da mistura de vários grupos étnicos; depois, que a cultura romana é produto de várias influências estrangeiras (enquanto as lendas gregas insistiam na pureza e continuidade das suas

\footnotetext{
${ }^{14}$ Que pode estar na origem de uma monarquia dualista ou ser a retroprojeção da ideia da colegialidade das magistraturas republicanas. Vide Grimal 1993 20-21; Cornell 199575 -77; Rocha Pereira 200925.
}

15 Cf. Plu. Publ. 21. 4-10; Suet. Tib. 1. 
tradições). A noção romântica de um assentamento de pastores levando uma vida virtuosa em simples cabanas convinha à ideologia augustana, mas já no séc. II a.C. os analistas acentuavam o contraste entre esta Roma primitiva e a decadência do presente, dando assim voz a um topos grato à historiografia latina. Esta função moralizadora está desde o início presente em Lívio (Praef. 10) quando afirma que, no estudo da história, se pode encontrar egrégios exemplos a imitar e atos vergonhosos a evitar.

A data tradicional para a fundação da cidade, que os historiadores e antiquários de finais da República colocavam em meados do séc. VIII a.C., não deve ser levada muito a sério. Tudo sugere que foi calculada de forma artificial ${ }^{16}$. A arqueologia mostra claramente que o lugar foi permanentemente ocupado séculos antes de 754 a.C. Em contrapartida, só relativamente tarde é que ocorreram mudanças na organização e estrutura da comunidade, do tipo que pode ser ligado ao processo crucial de urbanização e formação de um estado. Estes desenvolvimentos, que podem legitimamente ser definidos como uma fundação de uma cidade-estado, não são geralmente recuados para além de meados do séc. VII, portanto mais de cem anos depois da chamada "datação tradicional"17.

$\mathrm{Na}$ formação da urbe concorrem dois processos aparentemente contraditórios: enquanto a notícia do festival designado por Septimontium sugere um sinecismo de várias aldeias, a tradição literária aponta para a expansão de um núcleo original do Palatino. Mas a coexistência daqueles dois modelos é plausível. De forma semelhante, a ideia de uma evolução gradual pode conjugar-se com a de uma fundação, mediante uma reorganização e planeamento de uma cidade-estado, em finais do século VII, operada pelas elites locais, talvez devido à influência fenícia e grega no Mediterrâneo ocidental ${ }^{18}$.

${ }^{16}$ Sobre as dificuldades em harmonizar a cronologia tradicional relativa à fundação da cidade com os dados da arqueologia, vide infra. 2.3.

17 Vide Forsythe 2005 86. Opinião diferente em Carandini 2009 25-26.

18 Vide Forsythe 2005 91-93. 


\section{Período da Monarquia ${ }^{19}$}

Não se coloca atualmente em dúvida a existência de uma Monarquia em Roma, mas grande parte da nossa informação sobre esse período é lendária. Tradicionalmente, apontavam-se sete reis, alguns dos quais têm muito boas probabilidades de serem históricos. Nomes como Numa Pompílio e Tulo Hostílio são verosímeis, dada a sua relativa raridade, e não simples invenções, como o de Rómulo, se bem que os dados sobre os seus reinos sejam um misto de lenda e reconstituição antiquária consciente. É bastante claro que os primeiros reis são personalidades parcialmente ou completamente míticas. Paradoxalmente, algumas das ações que lhes são atribuídas podem ser mais facilmente atestadas que os seus putativos autores, como acontece com instituições atribuídas a Rómulo, o que equivale a dizer que a informação relativa a instituições e estruturas é mais fiável do que a relativa a pessoas e eventos.

Afigura-se provável que Rómulo não tenha sequer existido e que o seu nome seja um epónimo da designação da cidade: é uma forma de adjetivo e significa apenas 'romano'. Já antes se viu que a sua história é uma mistura complexa de lenda e contos populares, permeados de especulação antiquária e propaganda política. Os principais elementos da sua história são (depois da fundação da cidade e da guerra com os Sabinos) as campanhas vitoriosas contra Cenina, Fidenas e Veios, bem como a criação das instituições primitivas do estado romano. Com efeito, a tradição atribui a Rómulo a divisão da cidade em três tribos e trinta cúrias (unidades criadas para fins administrativos e políticos), bem como a fundação do senado, constituído por cem patres.

Numa Pompílio e Tulo Hostílio são pouco mais que estereótipos contrastantes, um pacífico e devoto, o outro aguerrido e feroz ${ }^{20}$. Ao primeiro, a tradição atribuía a criação das principais instituições religiosas do

19 Para uma visão crítica mais ampla sobre o período da Monarquia, é particularmente útil Cornell 1995 119-150, cuja análise norteou o essencial das posições assumidas nesta secção.

${ }^{20}$ As atribuições feitas a cada um parecem ter a ver com ideias sugeridas (ou espelhadas) pelos próprios nomes: Numa relacionado com numen 'poder divino' e Hostilius com bostis 'inimigo'. Vide Forsythe 200597. 
estado, incluindo o calendário (reformado com o intuito de tentar fazer coincidir tanto quanto possível os ciclos solares com os lunares, pela introdução de meses intercalares) e os sacerdócios (vestais, pontífices, âugures, flâmines, sálios).

Quanto à atividade de Tulo Hostílio, destaca-se a guerra contra Alba Longa, que deu o enquadramento para a lenda de Horácio, uma das mais famosas histórias dos Romanos ${ }^{21}$. A guerra em si, que levou à conquista de Alba Longa e do seu território, é histórica, no sentido em que a região dos Montes Albanos se tornou parte do território romano em dada altura da realeza e esse feito poderia, tanto quanto se sabe, ter sido obtido por um rei chamado Tulo Hostílio. A ele fica ligada a Cúria Hostília (mas trata-se de uma construção do século VI).

Anco Márcio, o quarto rei, aparece como uma combinação dos anteriores. Anco tinha origem sabina e era neto de Numa (pelo lado da mãe). A tradição atribuía-lhe a primeira ponte sobre o Tibre (Pons Sublicius), o alargamento do território romano até à costa e a fundação do porto de Óstia, junto à foz do rio. Os historiadores antigos revelaram alguma dificuldade em preencher o seu reinado com feitos. Os romanos de tempos mais tardios lembravam-no como um rei popular e filantropo 22 .

A Lúcio Tarquínio Prisco era atribuída uma origem parcialmente etrusca e foi bem sucedido na guerra, nas inovações constitucionais e na beneficência pública: construção do Circo Máximo e dos esgotos, início do templo de Júpiter, aumento das dimensões do senado e da cavalaria, instituição de jogos e divertimentos públicos. As suas vitórias militares foram conseguidas sobre Sabinos, Latinos e Etruscos.

Sérvio Túlio é o sexto rei e o mais complexo e enigmático de todos. As diferentes versões sobre a sua origem (servil, principesca ou por conceção divina), sobre a forma como obteve o trono e sobre a natureza

\footnotetext{
${ }^{21}$ Horácio era o vitorioso sobrevivente da batalha entre Horácios e Curiácios, dois grupos de três pessoas que combateram como campeões de Roma e Alba Longa, respetivamente. No seu triunfante regresso a casa, foi ao seu encontro a irmã, que havia desposado um dos Curiácios e, ao chorar a morte do esposo, foi morta por Horácio, num ato de raiva. Vide Cornell 1995 119-121.
}

22 Énio (Ann. 137 Sk.) e Lucrécio (3.1025) apelidam-no de bonus Ancus. 
das grandes medidas que institucionalizou são igualmente problemáticas. Com efeito, há uma dupla tradição relativa à sua origem: romana e etrusca. Não há dúvida, porém, de que as medidas que lhe são atribuídas (reorganização do corpo de cidadãos, construção de templos, edifícios públicos e fortificações, bem como importantes iniciativas em assuntos internacionais) assentam numa firme base histórica e, em alguns casos, podem ser confirmadas por informação independente: a divisão em quatro tribos, segundo a região da cidade; a divisão em centúrias (assente sobre a riqueza), que prevaleceu até ao final da República e até depois; a criação do census. Outro aspeto é que, ao contrário dos antecessores, não obteve o trono de forma regular, mas apoiou-se no poder popular, tornando-se não propriamente num rei, mas antes numa espécie de magistrado proto-republicano.

Tarquínio o Soberbo, último rei de Roma, é apresentado pura e simplesmente como um tirano. Filho de Tarquínio Prisco, atingiu o trono à força, depois de matar o seu sogro, Sérvio Túlio. Era cruel e caprichoso, mas também vistoso e bem sucedido. Sob o seu governo, Roma tornou-se no poder dominante na Itália central e essa prosperidade refletiu-se no desenvolvimento monumental da cidade. O corolário do seu reinado foi a construção do templo de Júpiter Capitolino, um dos edifícios maiores e mais impressionantes do mundo mediterrânico da altura. Assim que o templo ficou construído, Tarquínio foi expulso da cidade por um grupo de aristocratas, que instituíram a República, em substituição do seu governo.

\subsection{Caraterísticas e evolução da Monarquia romana}

Sobre a lista dos reis, há de certa forma duas posições extremas que podem ser tomadas: ou se parte do princípio de que é o produto forjado de nomes relevantes ligados às várias colinas da cidade (assumindo neste caso que Roma é resultado de um processo de sinecismo), ou se admite a ideia da tradição antiga de que se tratava efetivamente de uma monarquia não hereditária, hipótese que tem precedentes em sociedade arcaicas (de tipo homérico) em que o líder era o mais capaz de proteger a sociedade. 
De resto, a única exceção parcial seria a de Tarquínio Soberbo, que era filho de Tarquínio Prisco, mas esta exceção prova a regra, pois ele atingiu a realeza de forma ilegal, ao usurpar um trono do qual ficaria arredado em circunstâncias normais. Ou então trata-se da evolução para uma monarquia hereditária na passagem da fase de uma aldeia para a de uma cidade-estado 23 .

A interpretação generalizada, baseada na tradição literária, é de que a Monarquia romana se baseava numa espécie de sistema eletivo, que estaria na origem da instituição do interregnum da época republicana ${ }^{24}$. Depois da morte do rei, o poder voltava para o senado (res ad patres rediit), que estabelecia comissões para ocuparem o governo como interreges (reis interinos). O processo prolongava-se por um ano, depois do qual se procedia à reunião dos comitia curiata, nos quais o candidato proposto era votado pelo povo (através de uma lex curiata) e sancionado pelo senado (pela auctoritas patrum). Desta forma, os membros, os patres, não seriam elegíveis: faziam a escolha fora do seu círculo, medida que constituía uma forma de prevenir conflitos ${ }^{25}$. Tem sido aventada a suspeita de que tal procedimento fosse uma retrospeção dos historiadores a partir de uma prática republicana estabelecida posteriormente. Mas o nome (interregnum) sugere que o processo se baseia num procedimento do tempo dos reis, mesmo que na altura fosse diferente. Apesar de a questão continuar em aberto, subsiste, pois, a ideia de que o poder era conferido ao rei através de um processo de nomeação e ratificação ${ }^{26}$.

23 Na lenda dos antecessores de Rómulo, a dinastia hereditária existente em Alba Longa seria uma elaboração da antiquária. A realidade da Monarquia romana (e talvez de outras cidades itálicas) seria diferente. O princípio mantinha-se mesmo que o rei morto tivesse filhos, como aconteceu com Tarquínio Prisco, que sucedeu a Anco Márcio, apesar de este possuir dois filhos adultos. Numa também tinha filhos. Vide Cornell 1995 141; Forsythe 200598.

${ }^{24} \mathrm{O}$ procedimento continuou a aplicar-se em tempos da República, no caso de morte de ambos os cônsules ou então quando o ano terminava sem que tivesse havido a eleição de novos cônsules.

25 Os patres teriam sempre de ratificar a decisão tomada pelo povo: a chamada auctoritas patrum, até 399 a.C., era necessária antes que qualquer decreto popular se tornasse legalmente vinculativo. Os patres teriam assim um papel fundamental no processo, visível tanto no controlo do interregnum como no uso da auctoritas patrum. Cf. Scullard 1985 44-45; Cornell 1995 143; Southern 201127.

26 Vide Forsythe 2005110. 
De qualquer modo, havia conexões entre os reis e os seus sucessores. Por exemplo, ao possível sucessor era atribuído um cargo de importância no governo em curso: Tarquínio Prisco era o "braço direito" do seu antecessor, Anco Márcio, e será sucedido pelo seu próprio favorito, Sérvio Túlio. Essa ligação aparece também reforçada por laços de matrimónio: Sérvio Túlio era genro de Tarquínio Prisco e Tarquínio Soberbo era genro de Sérvio Túlio. Há, de resto, um elemento do conto popular nestas histórias: o motivo do estranho que casa com a esposa do rei e, assim, obtém o trono. As mulheres parecem, pois, desempenhar um papel de relevo na aclamação, como é o caso de Tanaquil, esposa de Tarquínio Prisco, que patrocinou a aclamação de Sérvio Túlio, e de Túlia, que incentivou o marido, Tarquínio o Soberbo, na usurpação do poder e assassínio de Sérvio Túlio ${ }^{27}$.

Alguns reis eram estrangeiros (ou pelo menos de fora da terra): eram-no literalmente no caso de Numa, que era Sabino, e de Tarquínio Prisco, que tinha ancestrais gregos e etruscos. Alguns dos reis não possuíam sangue patrício: particularmente Numa e Tarquínio Prisco, que eram imigrantes, e Sérvio Túlio, sobre o qual um dos poucos aspetos em que as fontes concordam é que ele não era de nascimento patrício ${ }^{28}$. A tradição latina sobre Sérvio Túlio, que o apresenta como um escravo que se tornou rei, poderia ter sido de algum modo decalcada a partir do relato do rex nemorensis, isto é o 'rei do Bosque' de Diana em Arícia. Tratava-se de um procedimento arcaico, existente até ao Império, em que um escravo fugitivo podia encontrar proteção naquele santuário, assumindo o 'reinado' local depois de matar o antecessor. Ora a tradição refere a ascensão do escravo Sérvio Túlio na sequência do assassinato do antecessor e relaciona-o com a construção do templo de Diana no Aventino, santuário rival do de Arícia ${ }^{29}$.

27 Um exemplo clássico disso mesmo é a história de Eneias, que casou com Lavínia, filha do rei Latino e, com a morte deste, veio a tornar-se rei dos Latinos. Ainda assim, isto não significa que a sucessão em Roma passasse pela linha feminina, se bem que seja inegável que as mulheres assumem com frequência um papel importante. Cf. Cornell 1995142.

28 O status posterior das gentes dos Hostilii e dos Marcii mostra também que não eram patrícios.

${ }^{29}$ Forsythe 2005106. 
É possível que usurpadores tivessem tomado Roma por curtos períodos no final da Monarquia e princípio da República. Eram bem conhecidas da tradição etrusca e romana as aventuras guerreiras dos irmãos Aulo e Célio Vibena, a julgar pelas representações em que eles apareciam. A mais significativa é uma pintura de um túmulo de Vulcos ${ }^{30}$ : de um lado, uma representação inspirada na Ilíada, relativa ao sacrifício dos prisioneiros troianos, parece servir de chave de leitura; do outro, uma série de guerreiros surpreende um grupo de inimigos, mata-os e liberta um prisioneiro. Todos estão identificados e entre eles se contam os dois irmãos. Célio Vibena (Caile Vipinas) é libertado por Mastarna (Macstrna); e entre as vítimas figura, à direita, um Cneve Tarchunies Rumach, identificado como Gneu Tarquínio de Roma (Fig. 1). A presença deste nome sugere uma conexão com a história de Roma no tempo dos Tarquínios. Não se pode dizer com certeza que se trata de Tarquínio o Antigo: além de o nome deste ser tradicionalmente Lúcio ${ }^{31}$, a nomenclatura itálica recorre frequentemente a adjetivos criados a partir de topónimos, pelo que não indicam mais do que a origem (como o caso do próprio Tarquínio, oriundo de Tarquinium). O imperador Cláudio, que era um polígrafo e um perito em "etruscologia", num discurso ${ }^{32}$, com o qual procurava justificar a entrada de cidadãos da Gália no senado romano, fala da história do acolhimento de aristocratas estrangeiros na Roma arcaica, para destacar a versão sobre a origem de Sérvio Túlio. Se a conhecida tradição romana o dava como filho de Ocrésia, uma prisioneira de guerra, Cláudio acrescenta uma novidade: as fontes etruscas apresentavam-no como Mastarna, um fiel companheiro de um senhor da guerra, Célio Vibena, que, depois da desgraça deste, veio para Roma com o resto das forças do seu antigo amigo, se instalou no Célio e mudou o nome para Sérvio Túlio.

\footnotetext{
${ }^{30}$ François Tomb.

${ }^{31}$ Se bem que Lucius provém, segundo Lívio, do etrusco Lucumo, que significa 'rei'.

32 CIL XIII.1668. O discurso de Lugduno, descoberto numa placa de bronze em 1528.
} 

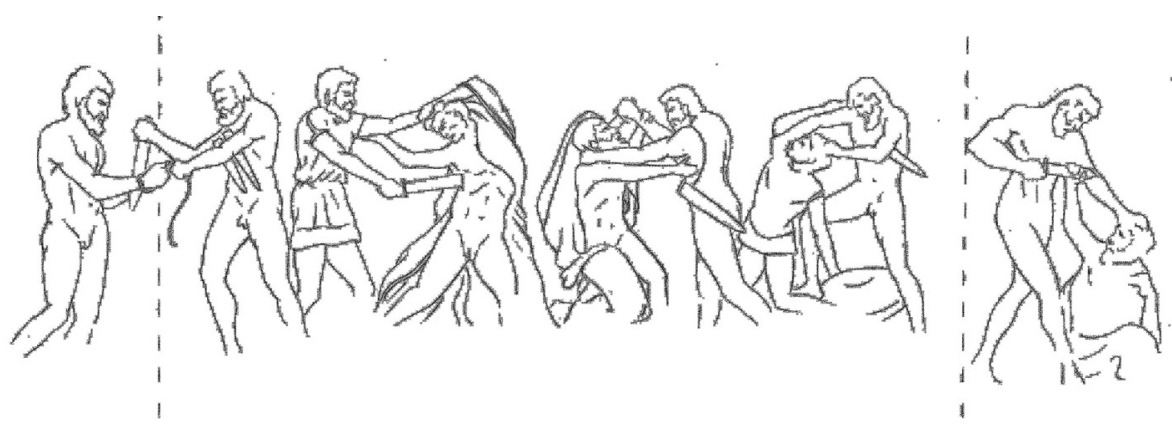

Fig. 1. Esboço do fresco do túmulo de Vulcos. Por Fábio Mordomo

Os eruditos interpretam o nome Mastarna (Macstrna) como composto de magister, seguido do sufixo etrusco - na, pelo que significaria 'comandante', denominação que ocorre nas funções de magister equitum ('comandante de cavalaria') ou magister populi ('comandante de infantaria' e equivalente de ditador), de que se falará no capítulo seguinte ${ }^{33}$. Contudo, Cláudio talvez se tenha precipitado na identificação, por estar demasiado preso à ideia de que os reis de Roma foram apenas sete. As dificuldades em identificar o servo de Tarquínio o Antigo com o fiel companheiro de Célio Vibena (a não ser que se identifique este com Tarquínio, o que é negado pelo referido fresco tumular) e os percursos paralelos, sugerem que se tratará de outra pessoa, o que pressupõe a existência neste período de mais governantes em Roma do que a tradição analística regista, e ainda que aristocratas lutavam pelo poder à frente de exércitos privados. Se Cláudio diz que Mastarna ocupou o Célio com a parte restante do exército de Célio Vibena, outra tradição relaciona o irmão deste, Aulo Vibena, com o Capitólio ${ }^{34}$.

Em suma, as fontes parecem indicar que o rei era uma pessoa de fora, por vezes mesmo um estrangeiro, e em qualquer dos casos exterior à aristocracia patrícia; que a sua eleição era um processo complexo (envolvendo o rei anterior, o senado, o povo e a consulta dos deuses). Em todo

33 Cornell (1995 233-235) não descarta a hipótese de Sérvio Túlio ser uma espécie de magistrado pré-republicano - um magister populi que poderia estar na origem da ditadura.

34 Vide Scullard 1985 31; Cornell 1995 130-150; Forsythe 2005 102-105; Kovaliov 2007 $55-56$. 
o caso, no período final da monarquia, estas regras terão sido subvertidas e o poder terá caído na mão de usurpadores e tiranos. Em consequência, senhores da guerra dominariam a Itália Central desde meados do séc. VI até finais do V.

\subsection{A cronologia tradicional e os dados da arqueologia}

A duração da realeza constitui também uma discrepância, pois a tradição estende-a por cerca de dois séculos e meio, recuando desde a queda de Tarquínio até à fundação da cidade em 754/3 a.C. Sobre esta data, fornecida por Varrão, cai a suspeita de ser uma reconstituição $\operatorname{artificial~} \operatorname{tardia}^{35}$. No entanto, já vimos que a arqueologia sugere que a fundação da cidade-estado tenha ocorrido apenas na parte final do séc. VII. Para Cornell (1995 121 ss) há duas formas de resolver o problema: reduzir o período de realeza, aceitando que, ao todo, os monarcas terão reinado c. 120 anos em vez dos 240 da tradição; ou então assumir que houve um maior número de reis ${ }^{36}$. Talvez haja, aliás, boas razões para fazer ambas as coisas: não só a lista dos reis deve estar incompleta, como a melhor forma de resolver a discrepância entre a tradição e os dados arqueológicos é colocar todos os desenvolvimentos históricos do período real (incluindo os próprios reis, se forem autênticos) no arco cronológico compreendido entre c. 625 e c. 500 a.C.

A discussão da cronologia dos Tarquínios pode ajudar a clarificar esta questão. É cronologicamente impossível que Tarquínio o Soberbo seja filho de Tarquínio Prisco, como a tradição sustenta. Dionísio de Halicarnasso interrompe propositadamente a narrativa e empenha dois capítulos a expor o que ele designa por absurdos da tradição ${ }^{37}$. A tradição orientalizante

35 De facto, multiplicando 7 gerações de reis por 35 anos e somando-lhe a datação do início da República, obtém-se a data fornecida por Varrão: $509+(7$ x 35) = 754. Além disso, descortina-se uma certa simetria nos anos de reinado, como assinala Forsythe 2005 98-99. Vide ainda Cornell 1995 72-73.

36 Parece improvável que 7 reis ocupassem um período de 244 anos (a média da coroa britânica é de 22 anos por rei).

37 D.H. 4.6-7. É impensável que Tarquínio Prisco, que chegou ao trono em 616 quando já era homem maduro, tenha nascido 150 anos antes da morte do filho em 495. 
faz de Tarquínio Prisco filho de Demarato, aristocrata de origem coríntia, ligado portanto à influência coríntia na Etrúria e no Lácio. Mas tal levanta problemas cronológicos complicados, como já acontecera com a ligação de Rómulo a Eneias e de Numa a Pitágoras ${ }^{38}$. São dados de uma manipulação secundária. Talvez os dois Tarquínios fossem um só, uma vez que aos dois se atribui a construção dos esgotos, desenvolvimento do Circo e o templo de Júpiter no Capitólio. Além disso, a arqueologia prova que os troços sobreviventes da muralha atribuída a Sérvio Túlio não são anteriores ao século IV, o que contradiz a tradição literária.

As incoerências da tradição sugerem, na verdade, outra cronologia: o reinado dos Tarquínios (terminado em 509) não teria durado mais que duas gerações, pelo que teria de haver começado entre 570 e 550 . Por conseguinte, a tradicional data de 616 não merece crédito. A vantagem do terminus a quo proposto é deixar espaço para os reis anteriores. Ora os desenvolvimentos institucionais (tribos e Cúrias), religiosos (cultos e calendário) e militares (definição de um território e de um exército efetivo) não podem ser anteriores à formação de Roma como cidade-estado, facto que aconteceu nas últimas décadas do séc. VII. O primeiros reis, a serem pessoas com existência histórica, teriam de ser colocados entre 625 e $570^{39}$.

Mas esta solução não é pacífica: a maioria dos estudiosos modernos opta por manter a datação tradicional, assumindo que os primeiros reis viveram na fase pré-urbana da cidade. De resto, a discussão continua, pois a arqueologia traz frequentemente à luz novos dados que obrigam a

Uma vez que Prisco morreu em 578, o seu filho deveria ter pelo menos 80 anos quando lutou na batalha do lago Regilo (499 ou 496). Mais: a esposa do primeiro, que era uma mulher em 616, terá acompanhado o segundo a Roma. Alguns historiadores citados por Dionísio dizem que Tarquínio seria filho de um segundo casamento; Dionísio segue a solução do analista L. Calpúrnio Pisão (séc. II a.C.), segundo o qual o Soberbo seria neto do primeiro. Mas tal hipótese é uma nítida racionalização contra a tradição mais antiga (incluindo Fábio Pictor).

38 De quem seria discípulo; mas Numa viveu dois séculos antes do suposto mestre.

39 Os dados da arqueologia apoiam esta datação: a $1^{\text {a }}$ construção da Regia, atribuída a Numa, data das últimas décadas do séc. VI; traços de uma construção arcaica (640-580) no norte do Comitium, datada do início do séc. VI, tem sido identificada com a Cúria Hostília construída, segundo a tradição, por Túlio Hostílio. Também é essa a data da primeira construção do Comitium, atribuído a Hostílio por Cícero, Rep. 2.31. Vide Cornell 1995 121-129. 
reformular as hipóteses. Com efeito, apesar de todas aquelas objeções, há historiadores que retomam com legitimidade a data tradicional de Varrão (da fundação em meados do século VIII) com base em novas escavações no núcleo de Roma ${ }^{40}$.

Por outro lado, a teoria moderna de que o reinado de Tarquínio introduziu um efetivo domínio etrusco que veio trazer grandes inovações em Roma está hoje posta em causa por não ter fundamento nem na historiografia nem na arqueologia ${ }^{41}$. Os historiadores modernos partiram do preconceito da superioridade da cultura etrusca, quando o que existia seria mais uma koine cultural tirrénica. A presença de Tarquínio em Roma inscreve-se na mobilidade horizontal entre comunidades da região, isto é, num tipo de mobilidade em que as personalidades mantinham o seu estatuto social ${ }^{42}$.

\subsection{Instituições da época monárquica}

Sociedade. A família era a célula fundamental da sociedade romana, e à testa de cada família estava o pai (paterfamilias), o elemento masculino mais velho, que detinha plenos poderes, inclusivamente de vida ou de morte sobre os filhos. Este núcleo enquadrava-se por sua vez numa organização gentilícia, na medida em que várias famílias partilhavam um nome de uma mesma gens (clã). Os cidadãos ostentavam três nomes ${ }^{43} \mathrm{e}$ apresentavam em segundo lugar a designação da sua gens: o nomen. Ligada à família e à gens estava outra instituição romana que perdurou: a clientela. Esta instituição parece ter origem na libertação de antigos escravos ou adscrição de homens livres ao clã (por exemplo, estrangeiros ou outros

\footnotetext{
40 Vide Carandini 2009 25-28.

41 Muitos estudiosos modernos continuam a considerar que a transformação da comunidade na parte final do séc. VII coincidiria com a chegada dos Tarquínios, iniciando-se uma fase de governo etrusco. Tal pressuposto constitui para Cornell (1995 121-122 e n.6) um dos mais perniciosos erros que obscurece correntemente o estudo da Roma arcaica e que não tem confirmação nem na tradição escrita nem na arqueologia. Vide Rocha Pereira 2009 23-24.

42 Forsythe 205 99-101.

43 Os tria nomina, constituídos por praenomen (nome próprio) nomen (da sua gens) e cognomen (espécie de alcunha de família).
} 
desprotegidos), mas acabou por se generalizar e regular as relações sociais entre pessoas de diferentes estatutos, pelo que não se reduzia a uma relação entre ricos e pobres. A ligação entre patronos (patroni) e clientes (clientes) baseava-se na fidelidade (fides), regulada pelos costumes e pela religião (e mais tarde pela lei das XII tábuas), em que o patronus estava obrigado a proteger o cliens economicamente e judicialmente, e o cliens estava obrigado a prestar serviços e apoiar o patronus, inclusivamente na guerra. O número de clientes conferia, na mesma proporção, prestígio e poder ao patronus.

A tradição romana fala também da oposição entre duas ordens: patrícios e plebeus, embora a distinção e identificação não seja pacífica. Há várias teorias que tentam explicar a misteriosa origem desta dicotomia: distinção política, origens étnicas diferentes, tribos diferentes ou diferenças económicas. Os patrícios seriam uma minoria (a tradição fala de 300 famílias). Os plebeus não seriam talvez todos os outros, mas eram igualmente cidadãos, organizados em gentes. Esta oposição terá sido mais notória no início da República, período em que os patrícios parecem ter-se fechado sobre si e assumido a exclusividade no acesso aos cargos políticos e religiosos, bem como o controlo do direito, o que gerou conflitos ${ }^{44}$.

Órgãos do governo. O poder na cidade-estado de Roma estava repartido, pelo menos no final da época monárquica, entre o rei, o senado e o povo. O rei era o chefe militar e teria poder judicial e religioso. Não se conhecem bem os seus poderes. Supõe-se que fosse eleito através de um processo de nomeação e ratificação que envolvia o povo e os aristocratas, mas não se sabe até que ponto o seu poder estaria associado à vontade do povo e do senado.

Supõe-se também a existência de um conselho consultivo do rei, um senado (de senex 'ancião') que se reuniria na Curia Hostilia. No interregnum, cada senador governaria por turnos, como atrás se viu

44 Vide Scullard 1961 38-48; Cornell 1995 289-292; Forsythe 2005 216. Cf. infra Nuno Simões Rodrigues, "Dos conflitos de ordens ao estado patrício-plebeu". 
(supra 2.1), a propósito da eleição do novo rei. Segundo a tradição, Rómulo nomeou 100 senadores, Tulo Hostílio duplicou-os e Tarquínio o Antigo elevou-os para 300, número que se manteve até Sula. Não há certezas sobre os seus poderes e forma de seleção, mas o processo usado seria mais flexível do que durante a República e dependeria da escolha do rei.

O povo, no seu conjunto, estaria inicialmente dividido em cúrias ${ }^{45}$ : seriam em número de 30 e vinham atribuídas a Rómulo. Estas estariam por sua vez divididas em grupos de 10, constituindo assim as 3 tribos: Ramnenses, Titienses e Luceres ${ }^{46}$, designações que foram preservadas em centúrias de cavalaria. Esta organização serviria de base para o recrutamento militar e para a constituição das mais arcaicas assembleias de voto, os comitia curiata ('assembleias por cúrias'), que foram ultrapassadas durante a República e restringidas a funções muito específicas $^{47}$. Na monarquia conferiam o poder (imperium) ao rei, embora não o escolhessem ${ }^{48}$.

A reforma atribuída a Sérvio Túlio propõe uma organização territorial (e não gentilícia) das tribos: 4 urbanas: Palatina, Suburana, Colina e Esquilina; e várias rústicas $\left(16\right.$ a 26) ${ }^{49}$. Além disso, instituiu-se uma classificação de acordo com a riqueza. Convém, no entanto, ter em conta

45 Derivado talvez de co-uiria (relacionado com uir 'homem'): 'associação de homens'.

46 Nomes que, segundo a tradição, derivariam respetivamente de Rómulo, de Tito Tácio e de Lucero, este um guerreiro etrusco que ajudara Rómulo nas lutas com os Sabinos. Está hoje posta de lado a ideia de que as tribos corresponderiam a uma divisão étnica entre Romanos (conotados com o Palatino), Sabinos (associados ao Quirinal) e Etruscos (ligados ao Célio). A organização em 30 cúrias pode ser da segunda metade do século VII a.C., anterior portanto a uma organização hoplítica (que parece estar na base dos comitia centuriata), colocada normalmente no século VI. Vide Cornell 1995 114-118; Forsythe 2005 108-115. Já Carandini 2009 22-23 e 27-28 considera as curiae como uma forma de articulação das colinas (septimontium) na fase proto-urbana de Roma: entre 850 e 750 a.C., uma vez que retoma a ideia romana de que a cidade foi fundada no século VIII a.C.

47 Para aprovar a lei (lex curiata de imperio) que atribuía o poder (imperium) a cada magistrado superior. Mas também para testemunho de testamentos e um tipo de adoção conhecido como adrogatio (que, como o nome indica, era efetuada através de uma proposta de lei - rogatio - resquício do poder legislativo dos comitia curiata).

48 Estas assembleias (comitia curiata) foram reduzidas a uma formalidade durante a República, pelo que cada cúria era representada apenas por um lictor.

49 Número que cresceu depois até atingir 35 tribos. 
que o que se conhece é produto da evolução até ao século II a.C. A população de Roma (patrícios e plebeus) encontrava-se dividida em 5 classes, de acordo com os rendimentos. Os mais ricos estavam na primeira classe. Os restantes entravam nas 4 classes inferiores (infra classem). No final, figuravam os desprovidos de posses: proletarii (cuja riqueza era apenas a prole) e capite censi (recenseados por cabeça). A origem de tal organização era nitidamente militar, tanto que os elementos de cada classe usavam armamento pago por si de acordo com as suas posses: os da primeira classe usavam armamento completo e nesta classe estavam também incluídas as 18 centúrias dos cavaleiros e mais 2 de engenheiros; o conjunto reunia-se no Campo de Marte, portanto fora do recinto sagrado da cidade (pomerium). A distinção inicial far-se-ia provavelmente entre classis e infra classem, isto é entre os que levavam armamento completo (infantaria pesada) e os mais levemente armados (infantaria ligeira), embora as tentativas de reconstrução sejam discutíveis ${ }^{50}$. Mais tarde, esta distinção foi substituída pelo sistema complexo das 5 classes, uma vez que a finalidade militar de tal classificação foi substituída pela fiscal e política (eleitoral). Cada classe detinha um número de centúrias, de que resultava outra assembleia: os comitia centuriata ('assembleias por centúrias'), nos quais a votação se operava por centúrias, um voto por cada uma. A primeira classe tinha mais centúrias ${ }^{51}$, pelo que determinava a votação. Cada centúria estava ainda dividida em mais velhos (seniores) e mais novos (iuniores). Assim se dava a primazia no voto à riqueza e à idade. Esta reforma deve ser posterior a Sérvio Túlio. Ainda assim, não se poderá negar todos os dados da tradição: ao período dos reis pertencerá a admissão dos plebeus na legião. Trata-se de um avanço no sentido da propriedade privada, em vez do poder gentilício.

50 Classis significava então 'exército'. Para uma análise da origem militar e posteriores desenvolvimentos da organização por centúrias, vide Cornell 1995 181-190.

${ }^{51}$ A $1^{\mathrm{a}}$ classe contava 80 centúrias +18 de cavalaria (98); a $2^{\mathrm{a}}$, $3^{\mathrm{a}}$ e $4^{\mathrm{a}}$ tinham 20 ; e a $5^{\mathrm{a}}$ 30). Havia ainda as supranumerárias: além das 2 de engenheiros, existiam 2 de tocadores de trompa e 1 de proletários. Eram no total 193. Como se vê, o número de indivíduos de cada centúria já não era 100, nem fixo. As classes mais baixas, embora tivessem menos centúrias, continham a maior parte da população. O poder de voto era assim subordinado a uma plutocracia. Vide Forsythe 2005 111-115. 
A Monarquia da tradição romana chega-nos, portanto, distorcida pela projeção retrospetiva e especulação dos historiadores do final da República, operadas por motivos patrióticos, morais, políticos ou familiares. Mas, apesar de em grande parte obscura e lendária, está na génese de várias das instituições sociais, políticas e religiosas que depois se mantiveram ou desenvolveram na época republicana - como o interregnum, a figura do rex sacrorum ou os símbolos associados ao poder. Hoje é claro que, no final da Monarquia (no séc. VI a.C.), Roma era já uma cidade grande e desenvolvida nas instituições e na arquitetura, poderosa no Lácio e no Tirreno, com relações políticas, culturais e comerciais inclusivamente com Cartago, com quem em breve iria celebrar um tratado.

\section{Tábua Cronológica}

c. 1000 a.C. - Ocupação do Palatino

$754 / 753$ a.C. - Data tradicional da fundação de Roma

c. 625 - Começo da cidade-estado/data da fundação para alguns

616 - Data tradicional do início do reinado dos Tarquínios

c. 570-550 - Mais provável início do reinado dos Tarquínios

509 a.C. - Data tradicional da queda da Monarquia e implantação da República

\section{Bibliografia}

Alföldi, A. (1971), Early Rome and the Latins. Ann Arbor, University of Michigan Press.

Carandini, A. (2009), Roma. Il primo giorno. Bari, Laterza.

Centeno, R. (coord.) (1997), Civilizações Clássicas II. Roma. Lisboa, Universidade Aberta.

Cornell, T. J. (1995), The Beginnings of Rome. London, Routledge.

Finley, M.I. (1985), Ancient History: Evidence and Models. London, Penguin.

Forsythe, G. (2005), A Critical History of Early Rome. Berkeley/London, University of California Press.

Grandazi, A. (1991), La fondation de Rome. Reflexion sur l’histoire. Préface de P. Grimal. Paris, Les Belles Lettres.

Grimal, P. (1984), La civilisation romaine, trad. port. (1993), A civilização romana. Lisboa, Edições 70.

Holloway, R. (c.1996 reimp. 2000), The Archaeology of Early Rome and Latium. London, Routledge. 